\title{
Chronic pain, social withdrawal, and depression
}

\author{
This article was published in the following Dove Press journal: \\ Journal of Pain Research \\ 15 September 2014 \\ Number of times this article has been viewed
}

\section{Rebecca Arden Harris \\ Department of Family and Social Medicine, Montefiore Medical Center/ Albert Einstein College of Medicine, Bronx, NY, USA}

Correspondence: Rebecca Arden Harris Department of Family and Social Medicine, Montefiore Medical Center/ Albert Einstein College of Medicine, Bronx, New York, NY, USA

Email rebecca.arden.harris@gmail.com
Wallace et $\mathrm{al}^{1}$ used an effective combination of qualitative methods, ie, photographs taken by patients with accompanying narratives, interviews, and focus group sessions, to elicit descriptions of the daily realities of living with chronic pain from the patient perspective. The details are intimate and poignant. Patients tell of how they must curtail everyday activities in order to cope with the discomfort, of their frustration in trying to relay their situation to others, and of their despair at the thick-skinned reception they sometimes get because pain presents differently from other ailments. Primary care physicians will learn a lot from these images, particularly with regard to depression as a comorbidity of chronic pain.

I would like to briefly conjecture on the connection between social withdrawal reluctantly acceded to and the emergence of depression. The patients in this study are keenly aware of how much effort is involved in maintaining an extended network of relationships. Family, friends, coworkers, neighbors, teachers - the entire dramatis personae that adults interact with on the daily stage - each requires a measure of continuous affirmation. In contemporary Western society, self-confidence and identity are assembled from the expressive bricolage of these interactions, from the receptions that are given and received. Once patients are constrained to pull back from ordinary activities, a large part of their social universe, and the affective life that depends on it, quickly deteriorates. The collapse of one's social world can precipitate feelings of panic, emptiness, anger, hurt, sadness, and a range of other emotions linked to depression. Primary care physicians should consider the possibility that depression arising from involuntary social isolation is not a psychiatric disorder, but a normal human reaction to the awful consequences of chronic pain. Here, surely, is an unambiguous warrant for an early, robust, and compassionate intervention, one aimed at relieving symptoms and restoring engagement, before irreparable damage has been done.

\section{Disclosure}

The author has no conflicts of interest in this work.

\section{Reference}

1. Wallace LS, Wexler RK, McDougle L, Miser WF, Haddox JD. Voices that may not otherwise be heard: a qualitative exploration into the perspectives of primary care patients living with chronic pain. $J$ Pain Res. 2014;7:291-299. 
Journal of Pain Research

\section{Publish your work in this journal}

The Journal of Pain Research is an international, peer-reviewed, open access, online journal that welcomes laboratory and clinical findings in the fields of pain research and the prevention and management of pain. Original research, reviews, symposium reports, hypothesis formation and commentaries are all considered for publication.

The manuscript management system is completely online and includes a very quick and fair peer-review system, which is all easy to use. Visit http://www.dovepress.com/testimonials.php to read real quotes from published authors.

\footnotetext{
Submit your manuscript here: http://www.dovepress.com/journal-of-pain-research-journal
} 